Acta vet. scand. $1968,9,328-349$.

From the Department of Pathology, College of Veterinary Medicine, Helsinki, Finland.

\title{
A STATISTICAL STUDY ON THE TUMOURS OF DOGS
}

\author{
By \\ Timo Rahko
}

A few excellent statistical investigations have been carried out concerning tumours of dogs. Perhaps the most representative statements are encountered in the numerous papers by Mulligan (1944a, b, 1948a, b, 1949a, b, c, 1963) and by Cotchin (1951, $1954 \mathrm{a}, \mathrm{b}, 1956,1959,1962)$. Moulton in his book "Tumors in Domestic Animals" (1961) attaches special importance to tumours of the dog, thus providing a relevant basis for tumour diagnostics.

In some investigations (e.g. Mulligan 1949c; Krook 1954; Larsson 1956, 1957; Cotchin 1962; Howard \& Nielsen 1965) the inference has been drawn that there exists a certain breedassociated disposition for tumours. Since the population of breeds varies in different countries and no detailed statistical studies concerning the tumours of dogs have so far been made in Finland, the author considered it appropriate to undertake the present study. In this paper it is the author's intention to present some data concerning the tumour distribution according to breed, sex, age, type of neoplasm, tumour localization, number of tumours and tumour metastasizing in dogs.

\section{MATERIAL AND METHODS}

The material investigated comprised 173 tumours in 164 dogs examined at the Department of Pathology of the College of Veterinary Medicine during the period 1.1.1965-31.5.1967. Autopsies were performed on 417 dogs, in 75 of which one or several tumours were present. Furthermore, samples of organs 


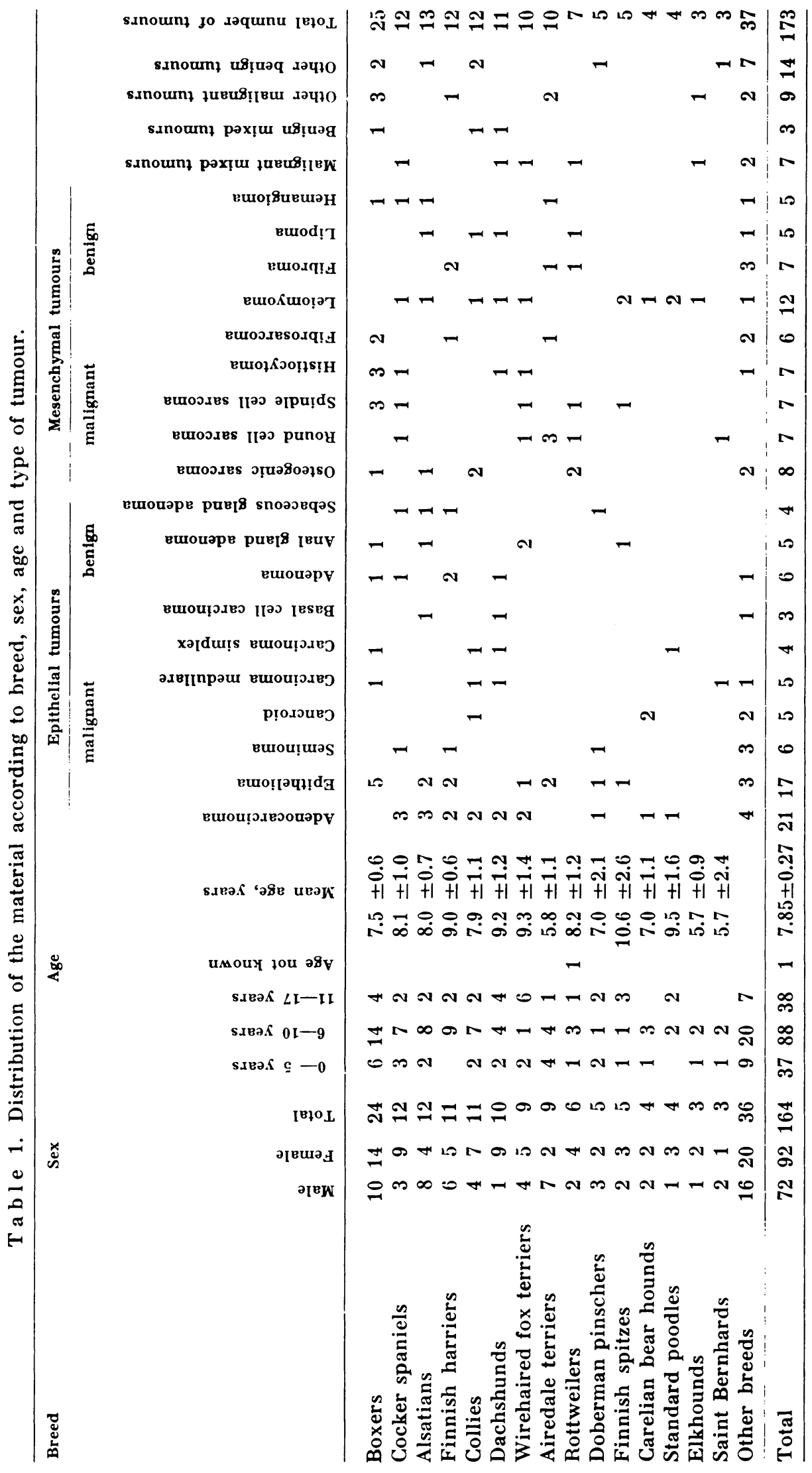


or biopsies from 145 dogs were examined. In 89 of them one or several tumours were established.

Tissue sections were fixed in $10 \%$ formaldehyde solution, embedded in paraffin, cut at $4-5 \mu$ and stained with haematoxylin-eosin. In a few cases other staining methods were applied.

The statements were based on microscopic routine examination and on tumour definition recorded in the relevant literature. In some of the above-mentioned cases more detailed investigations were carried out.

The statistical analyses were performed according to the $\chi^{2}$ test and Student's $t$ test. Yates' correction was respected. The presence of statistically significant differences is indicated as follows (Cramér):

* Statistically almost significant difference

* * Statistically significant difference

$(\mathrm{P}<0.05)$

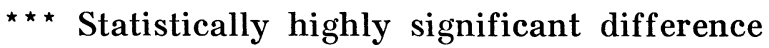

$(\mathrm{P}<0.001)$

\section{RESULTS}

Distribution according to breed. The dogs were classified according to the specification of breeds applied by the Finnish Kennel Association except in the case of Dachshunds, which are presented as a single group, owing to insufficient anamnestic data.

Table 1 shows the distribution according to breed. Table 2 presents the corresponding distribution of dogs with cutaneous tumours.

Most of the material came from Helsinki and its surrounding area. In order to draw a positive inference from the breed distribution, it would be necessary to know the breed distribution of all dogs in the corresponding geographical area. Unfortunately, information on Finland's canine population is incomplete. During the years 1955 - 1966 the Finnish Kennel Association registered a total of 109,376 dogs, $71.4 \%$ of them $(78,035)$ belonging to the 14 largest breed groups. According to information obtained from the Central Bureau of Statistics, the majority of all dogs are registered, and it may be concluded that the breed distribution of the dogs registered by the Finnish Kennel Association is fairly representative of the Finnish canine population. 


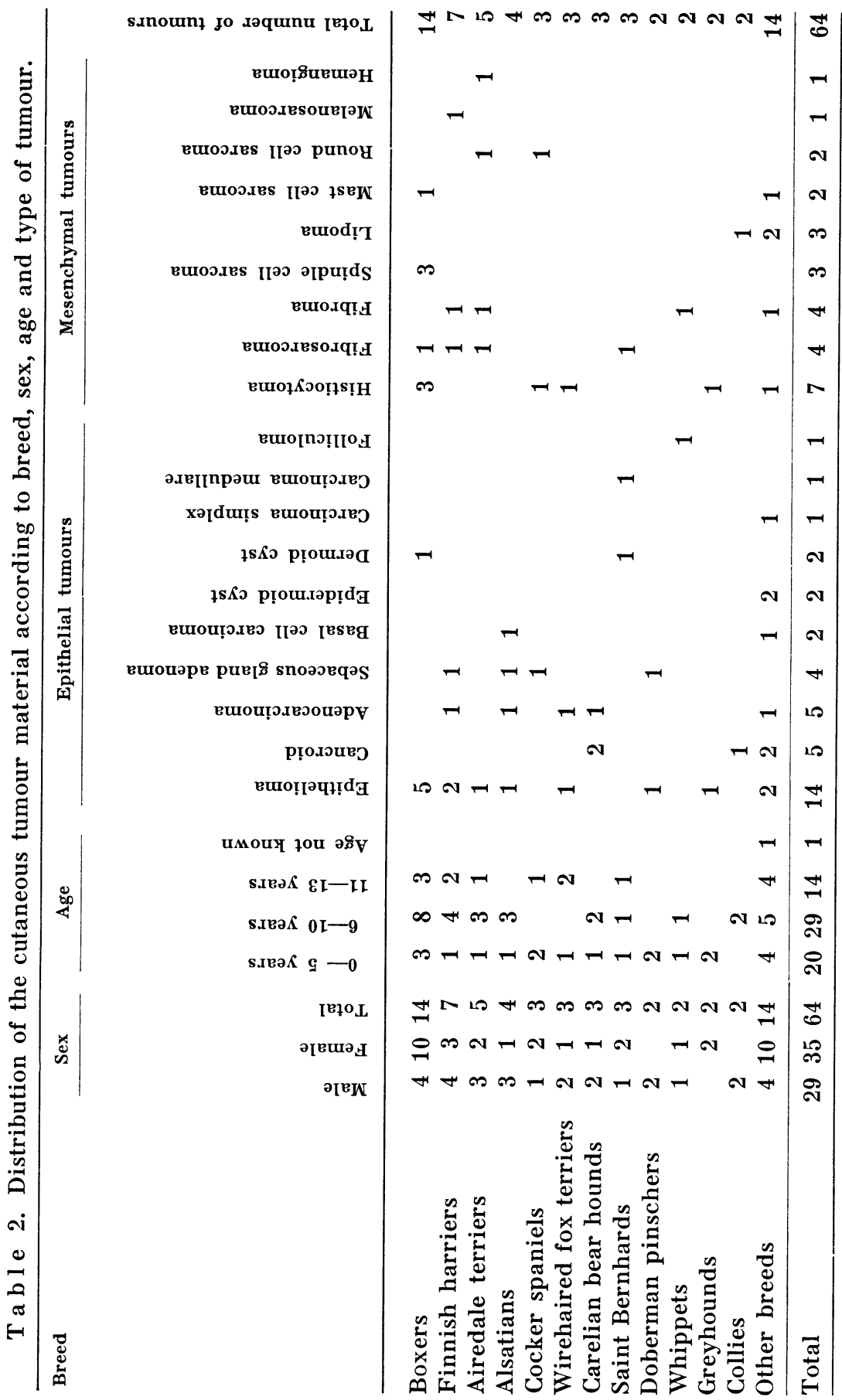




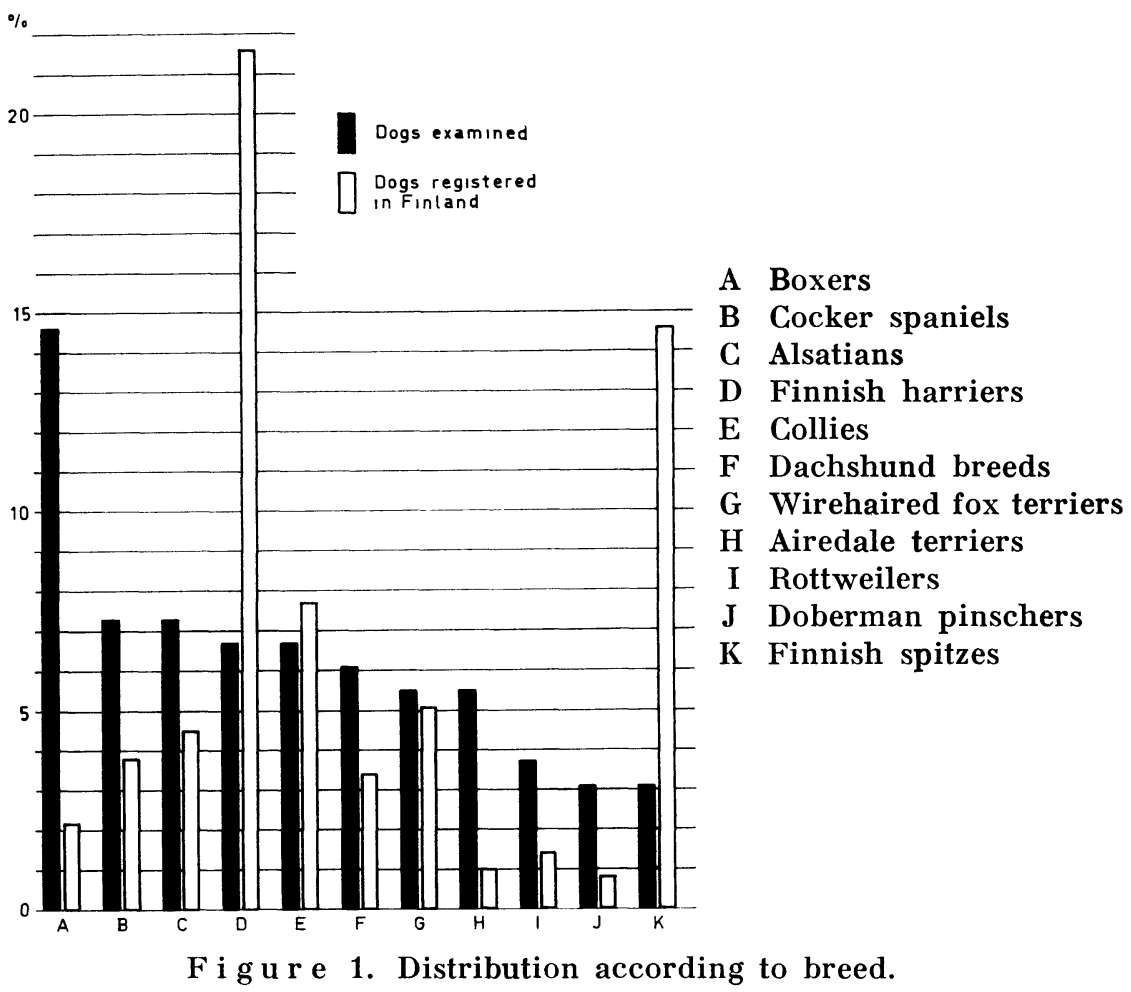

Table 3 and Fig. 1 show the distribution according to breed of the dogs examined and of all registered dogs for the breeds most numerously represented in the author's material. The diagram reveals that some of the breeds, especially those of the Boxers and Airedale terriers, are over-represented, while the Finnish harriers and Finnish spitzes are under-represented. It therefore seemed indicated to carry out a detailed investigation of which mathematical values can be obtained by statistical analysis for the over- and under-representation illustrated by Fig. 1.

Table 3 shows the distribution of dogs registered in 19551966 for the 14 largest breeds and the corresponding numbers of dogs in the present material. The table also contains the results of the $\chi^{2}$ test with respect to the breeds represented by 5 or more specimens in the material and the kind of representation of the respective breeds (over- or under-representation).

The over-representation of Boxers and Airedale terriers in the material is statistically highly significant, that of Doberman 
Table 3. Tumour frequency in different breeds.

\begin{tabular}{|c|c|c|c|c|}
\hline Breed & $\begin{array}{c}\text { Number } \\
\text { of dogs } \\
\text { registered }\end{array}$ & $\begin{array}{c}\text { Number } \\
\text { of dogs } \\
\text { examined }\end{array}$ & $\chi^{2}$ value & Representation \\
\hline Finnish harriers & 23,661 & 11 & $16.25^{\star \star \star}$ & under-representation \\
\hline Finnish spitzes & 16,018 & $\mathbf{5}$ & $14.28^{\star \star \star}$ & under-representation \\
\hline Collies & 8,449 & 11 . & - & - \\
\hline Wirehaired fox terriers & 5,662 & 9 & - & - \\
\hline Alsatians & 4,909 & 12 & 2.27 & over-representation \\
\hline Cocker spaniels & 4,144 & 12 & $4.53^{\star}$ & over-representation \\
\hline Carelian bear hounds & 3,761 & 4 & - & - \\
\hline Dachshunds & 3,646 & 10 & 2.91 & over-representation \\
\hline Boxers & 2,395 & 24 & $110.17^{\star \star \star}$ & over-representation \\
\hline Rottweilers & 1,578 & 6 & $4.01^{\star}$ & over-representation \\
\hline Airedale terriers & 1,125 & 9 & $27.24^{\star \star \star}$ & over-representation \\
\hline Pekingese & 1,084 & 2 & - & - \\
\hline Doberman pinschers & 875 & 5 & $7.88^{\star \star}$ & over-representation \\
\hline Dreevers & 768 & - & - & - \\
\hline
\end{tabular}

pinschers statistically significant, and that of Cocker spaniels and Rottweilers statistically almost significant. Furthermore it may be noted that the under-representation of Finnish harriers and Finnish spitzes is statistically highly significant.

Statistical analysis of the cutaneous tumour series revealed that Boxers and Airedale terriers are over-represented to a statistically highly significant extent $\left(\chi^{2}=105.0^{\star \star \star}\right.$ and $22.4^{\star \star \star}$ respectively). No statistically significant over-representation of any other breed was noted. Under-representation was suggested by the value found for Finnish harriers only $\left(x^{2}=2.88\right)$, yet without any statistical significance.

Mammary tumours were observed in 33 dogs, of which 8 were Dachshunds and 5 were Cocker spaniels. Statistical dominance of mammary tumours could be noted only in Dachshunds. In this group the dominance was statistically highly significant. Because of the small number of specimens available the frequency of mammary tumours in Cocker spaniels presented no statistical corroboration.

The mathematical $\chi^{2}$ values as such cannot be accepted as an expression of potential predisposition or resistance. The analysis was based on the 0-hypothesis, according to which the distribution in given breeds in the material is equivalent to that in the entire canine population. It has also been found that the age 
distribution in the total canine population and in the different breeds of dogs substantially influences the incidence of tumours, so that a high mean age results in over-representation, owing to increased predisposition for tumours (Krook 1954). No accurate studies exist concerning the breed and age distributions in dogs in Helsinki and its surrounding area. Examination of the breed distribution based on random samples taken from the register of the Finnish Kennel Association indicates that certain breeds of hunting dogs are less popular in Helsinki and its surrounding area than in rural areas. However, no data are available on the age distribution of the canine population in the Helsinki area. It is therefore difficult to present a proper assessment of tumour disposition in the present material. However, some breeds are over- or under-represented to such an extent (Table 3; Fig. 1) that it seemed indicated to investigate the causes responsible.

Boxers and Airedale terriers were statistically over-represented in the entire material and in the cutaneous tumour series to such an extent that predisposition for tumours can be considered the essential cause. In the case of other breeds, e.g. Doberman pinschers, Cocker spaniels and Rottweilers, over-representation may partly be due to some other cause than a delicate constitution. In Dachshunds no general tumour predisposition could be noted. However, mammary tumours were dominant among all neoplasms found in this breed. The frequent incidence of mammary tumours in Cocker spaniels could not be demonstrated with adequate statistical confidence.

The under-representation of Finnish harriers and Finnish spitzes is statistically highly significant. The mathematical under-representation may be due to the fact that the material comes from a geographical area where these breeds are represented in relatively smaller numbers than indicated by the breed distribution specified by the register used for reference. It is also possible that these breeds have lower mean ages than the other breeds in this area. However, one gets the impression that Finnish harriers and Finnish spitzes possess some kind of resistance against tumours. Since these breeds are by far the most popular ones in our country, a detailed investigation of their potential resistance on the basis of sufficiently extensive material and accurate data may be indicated.

The sex distribution of all dogs and of the dogs with cutaneous tumour is listed in Tables 1 and 2. Furthermore, the sex distri- 


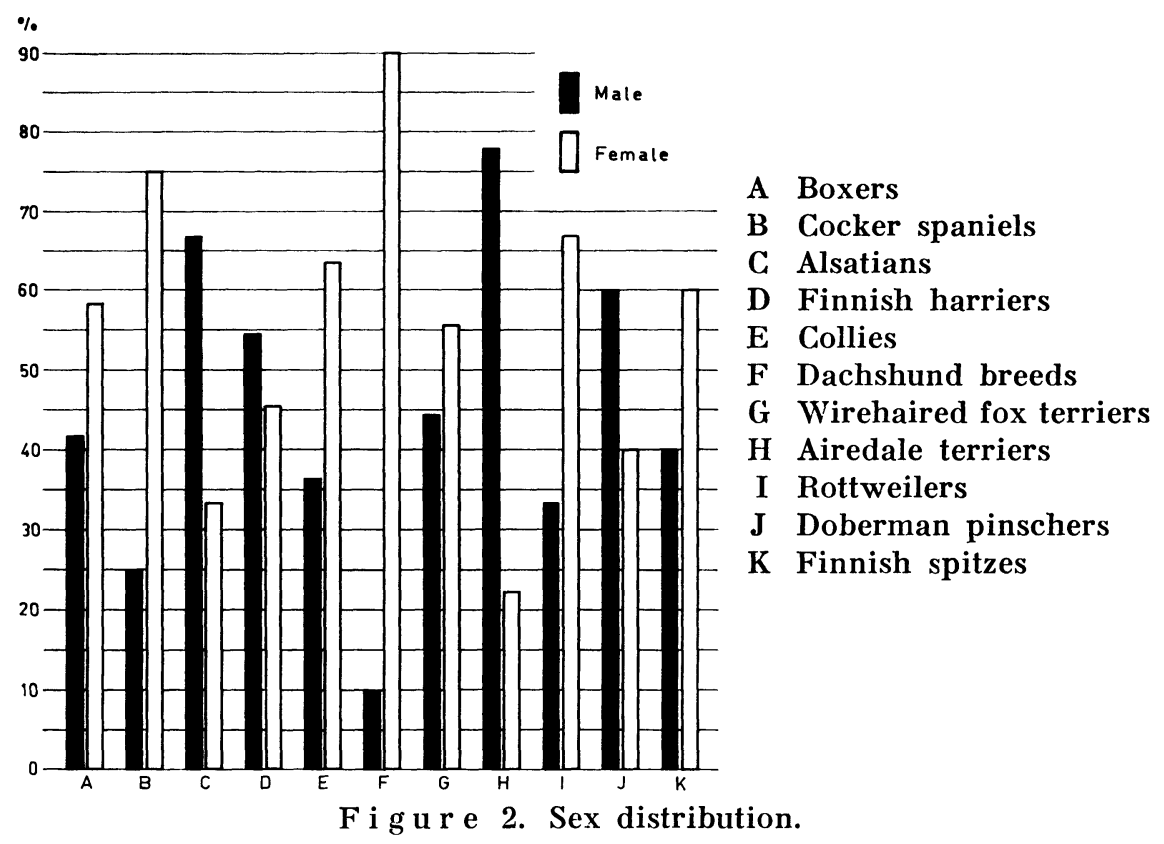

bution of the largest breed groups is shown in Fig. 2. The material comprised 92 females $(56.1 \%)$ and 72 males $(43.9 \%)$. Of the dogs with cutaneous tumour, $35(54.7 \%)$ were females and $29(45.3 \%)$ were males. No investigation has so far been made of the sex distribution in the canine population of Helsinki and its surrounding area. If this is assumed to consist of $50 \%$ of either sex, the over-representation of females has no statistical significance.

Tumours present in the genitals and mammary glands were decidedly more frequent in the females than in the males. Mammary tumours occurred in 33 females. Of 112 dogs with tumours not merely confined to the genitals and mammary glands, 50 $(44.6 \%)$ were females and $62(55.4 \%)$ were males.

It may be observed that owing to the high incidence of mammary tumours the females were over-represented, yet without statistical significance.

The age distribution in the different breeds is shown in Table 1. Table 2 contains the corresponding information about dogs with cutaneous tumours. The age of 163 dogs was known. In the case of one female Rottweiler with subcutaneous lipoma the exact age could not be established. 

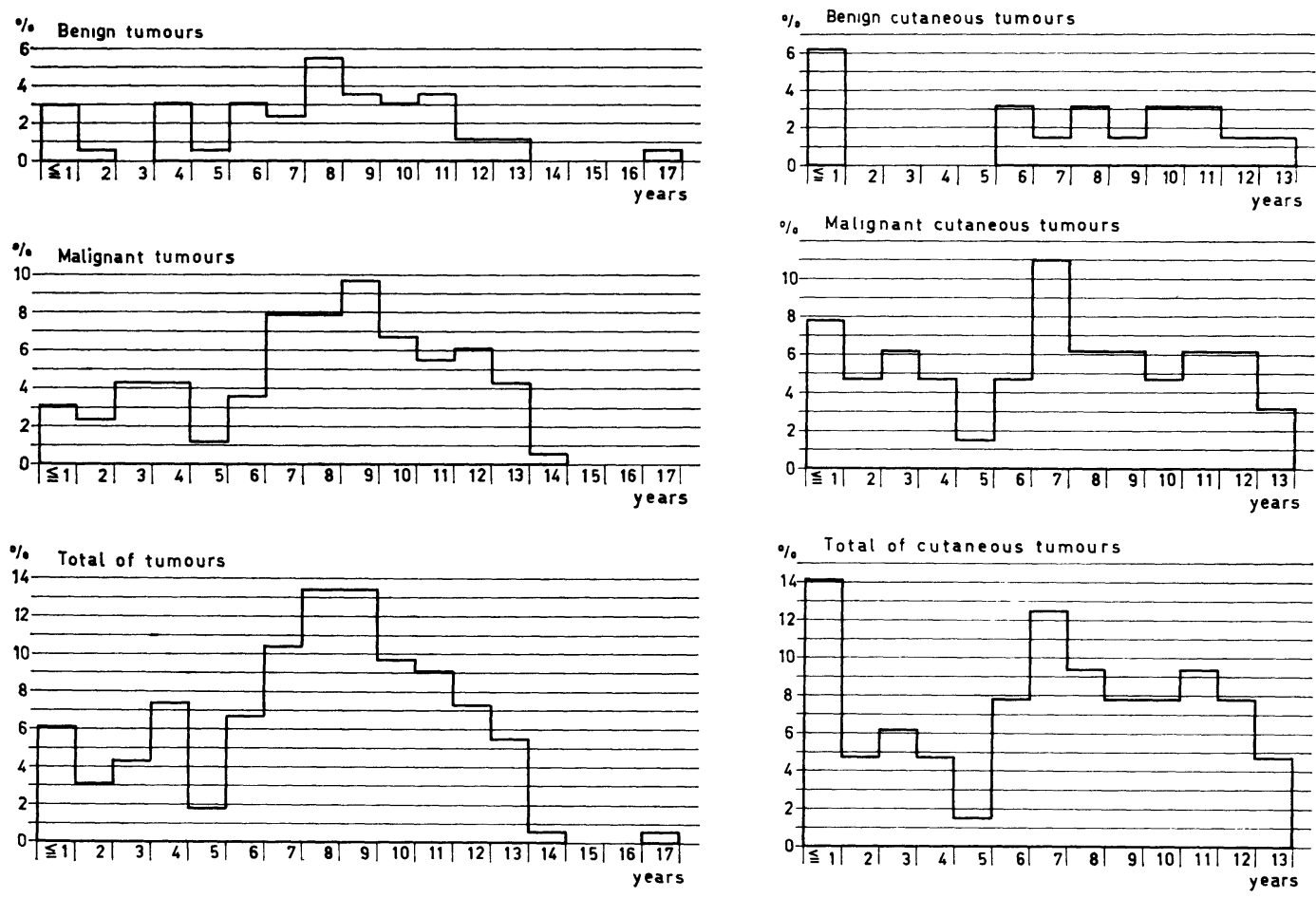

Figure 3. Age distribution.

Fig u re 4. Age distribution of dogs with cutaneous tumours.

The diagrams in Fig. 3 show the age distribution in the entire material, in dogs afflicted with malignant tumours and in dogs presenting benign tumours only. Fig. 4 contains the corresponding diagrams for dogs with cutaneous tumour.

The mean age of the 163 dogs was $7.85 \pm 0.27$ years. Dogs aged 8 to 9 years, which constituted the largest age group, accounted for more than $1 / 4$ of all dogs in the material. $76.8 \%$ of the dogs were 6 years or older.

The age distribution in 111 dogs with malignant tumour was fairly similar to that in all dogs, yet the older dogs were somewhat stronger represented. $77.5 \%$ of the dogs in this group were 6 years or older.

In 53 dogs with benign tumours only a more uniform age distribution was observed than in the preceding groups. However, compared with those the contribution of one-year-old and younger dogs was higher, amounting to $11.3 \%$. The dogs of 6 years or more accounted for $75.5 \%$. 
The 64 dogs with cutaneous tumours differed from all preceding groups in their age distribution (Fig. 4). Their mean age was $6.95 \pm 0.48$ years. These dogs were rather uniformly distributed in different age groups, excepting that of dogs aged 1 year or younger, which showed a relatively high incidence.

The 47 dogs presenting a malignant cutaneous tumour were fairly uniformly distributed among different age groups.

Of the $17 \mathrm{dogs}$ with benign cutaneous tumours, the 1-year-old and younger dogs constituted the largest group. No benign cutaneous tumours were noted in dogs between the ages of 2 and 5 years. Benign cutaneous tumours occurred in about equal number in the different age groups among the dogs of 6 years' age or older.

The mean age of the canine population in Helsinki and its surrounding area is evidently considerably lower than the mean age of the material. The canine population of the City of Stockholm had in 1947-1951 a mean age of 4.4 years (Tufvesson 1953). Although no corresponding study of the age distribution in dogs has been carried out in Finland, it may be assumed on the basis of the present material (however, without sufficient statistical confidence) that here, too, tumours are more often encountered in middle-aged or aged dogs.

The classification of tumours in the present study is based on morphological characteristics typical for different types of tumours. The biopsies and tissue specimens were examined by the usual methods. However, the clinical manifestation of the tumour was in some cases considered. The histiocytomas have been classified as malignant tumours, because of certain characteristics suggesting malignity observed in histological preparations, in spite of the fact that no metastases were established. The histopathology of certain mesenchymal tumours is intended to constitute the subject of a later report.

In Table 1 the types and numbers of tumours have been listed for the different breed groups. Table 2 contains the corresponding data with reference to the distribution of cutaneous tumours and tumours of the subcutaneous tissue.

Eighty epithelial tumours $(46.2 \%)$ were observed, of which $62(77.5 \%)$ were malignant. Tumours originating from mesenchymal and haematopoietic tissues and their derivatives were established in 76 cases $(43.9 \%), 41(53.9 \%)$ of which were malignant. The distribution of epithelial and mesenchymal tu- 


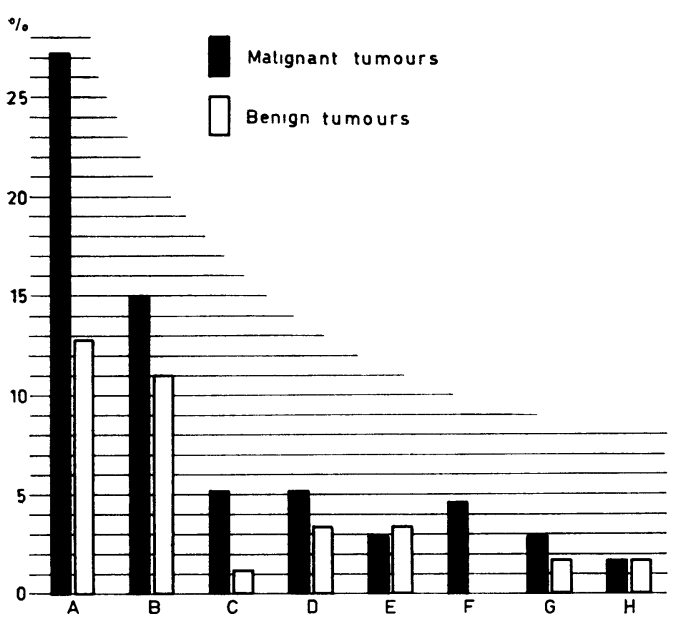

A Skin, subcutaneous tissue, anal glands

B Female genitals

C Male genitals

D Digestive tract

E Abdominal organs

F Bones

G Endocrine glands

$\mathrm{H}$ Other locations

Figure 5. Distribution of tumours according to organ and tissue groups.

mours showed no statistically significant difference. The material contained 112 malignant and 61 benign tumours (64.7 and $35.3 \%$ respectively). The dominance of malignant tumours is statistically highly significant in the entire material and also in the series of epithelial tumours.

Altogether 10 mixed tumours were established, 7 of them were malignant. The mixed tumours were all mammary tumours. In all cases glandular tumour epithelium occurred as a component. Four cysts were furthermore noted in the skin. The pigment-producing tumours were 3,2 of which were malignant.

There was no statistically significant difference in the distribution of the 64 cutaneous neoplasms among epithelial and mesenchymal tumours (57.8 and $42.2 \%$ respectively). Most of these tumours were malignant. Their dominance among all cutaneous tumours is statistically highly significant and among the epithelial cutaneous tumours statistically significant.

The distribution of the 33 mammary tumours revealed, too, a high incidence of malignant tumours. Their dominance among the mammary tumours is statistically significant.

In the different breed groups the distribution of the malignant and benign tumours showed a statistically significant difference only in the group of Boxers, in which dominance of malignant tumours was statistically almost significant.

The investigations concerning tumour distribution show a 


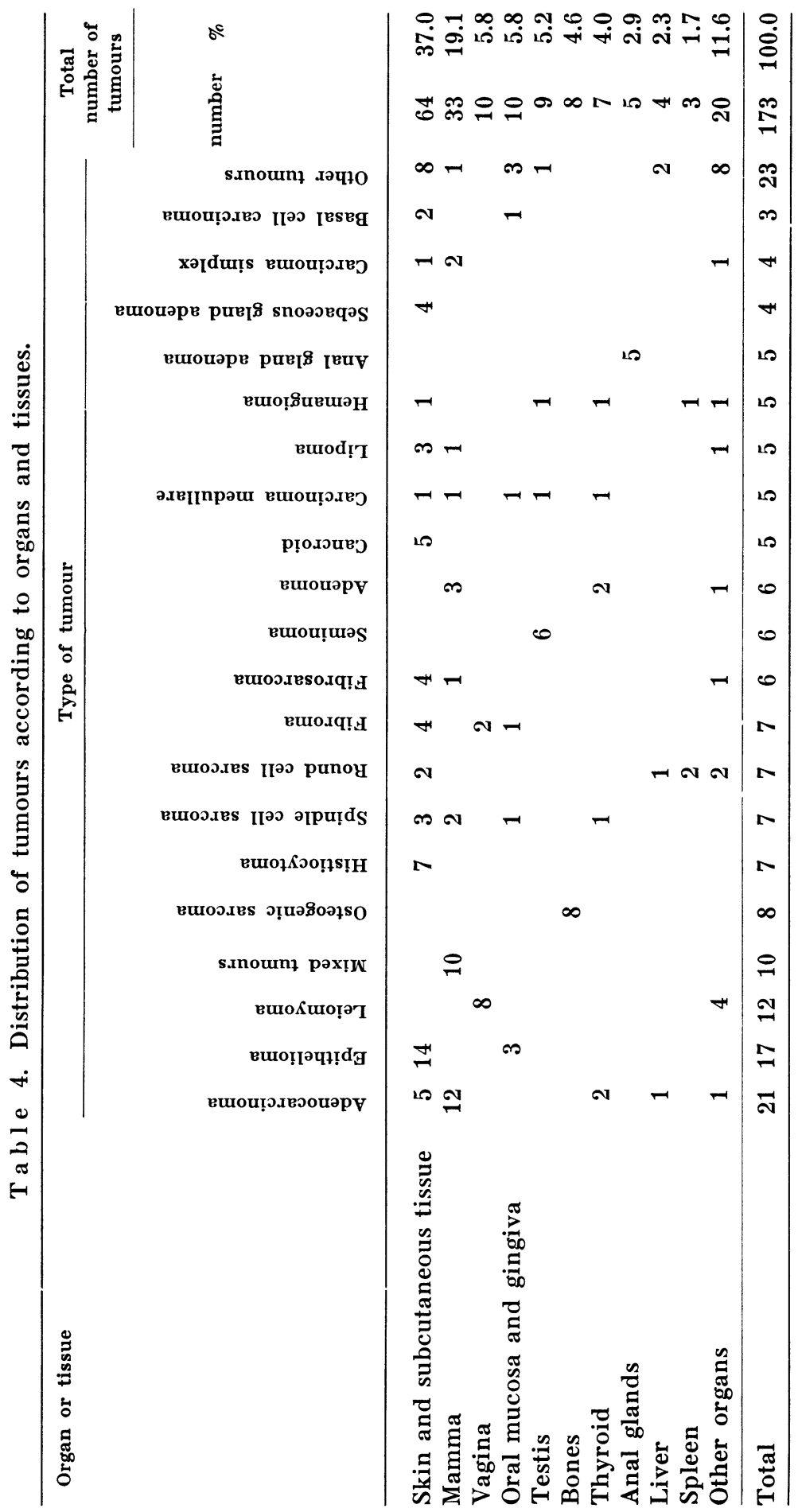




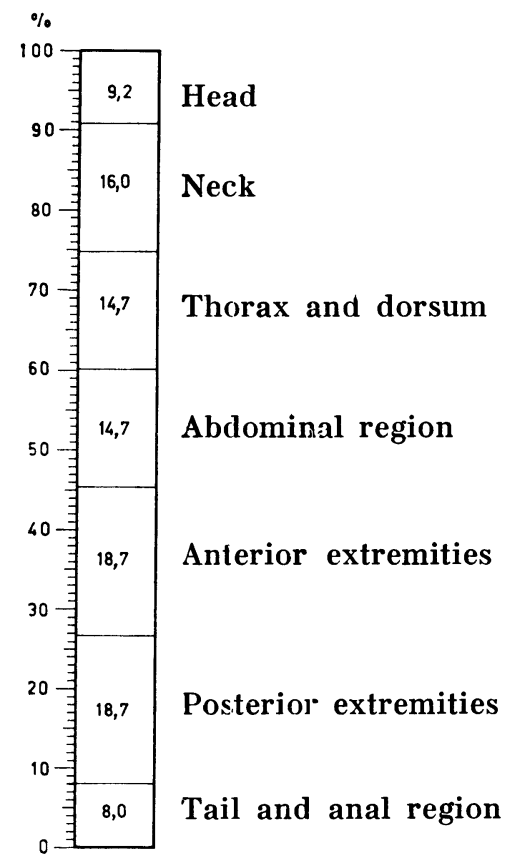

Figure 6. Regional distribution of cutaneous tumours.

conspicuously high incidence of malignant tumours. Their dominance among the epithelial tumours revealed a pronounced statistical significance. On the other hand, no statistically significant difference was established for malignant and benign mesenchymal tumours. As a consequence the carcinoma/sarcoma ratio is comparatively high $(1.5: 1)$. The present investigations indicate that the dominance of malignant tumours is primarily due to the common occurrence of carcinoma.

The distribution of tumours in different organs is elucidated by Table 4. The diagram in Fig. 5 presents the distribution of malignant and benign tumours in certain groups of organs. Slightly more than $50 \%$ of the tumours in the present series were established in organ or tissue samples received from the field. It is therefore reasonable to assume that superficial, easily noticeable and excisable tumours are common. The predominant groups consisted of cutaneous and subcutaneous tissue tumours, equivalent to $37 \%$, and mammary tumours of females, equivalent to $19.1 \%$. These neoplasms also dominated among the malignant 
Table 5. Distribution of multiple primary tumours according to breed, sex, age, type of tumour and organ.

\begin{tabular}{|c|c|c|c|c|c|c|c|c|}
\hline \multirow[t]{2}{*}{ Breed } & \multicolumn{2}{|c|}{ Sex } & \multicolumn{2}{|c|}{ Age } & \multicolumn{4}{|c|}{ Distribution of tumours } \\
\hline & 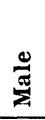 & 苞 & 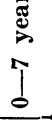 & $\prod_{\infty}^{\infty}$ & 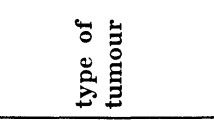 & 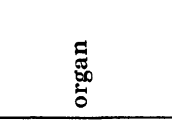 & 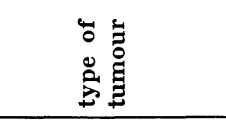 & \begin{tabular}{l}
5 \\
\multirow{5}{0}{} \\
0 \\
0
\end{tabular} \\
\hline Boxer & 1 & & & 1 & $\begin{array}{l}\text { spindle cell } \\
\text { sarcoma }\end{array}$ & skin & $\begin{array}{l}\text { anal gland } \\
\text { adenoma }\end{array}$ & anal gl. \\
\hline Wirehaired fox terrier & & 1 & 1 & & $\begin{array}{l}\text { spindle cell } \\
\text { sarcoma }\end{array}$ & mamma & leiomyoma & uterus \\
\hline Rottweiler & 1 & & & 1 & $\begin{array}{r}\text { osteogenic } \\
\text { sarcoma }\end{array}$ & scapula & $\begin{array}{r}\text { round cell } \\
\text { sarcoma }\end{array}$ & spleen \\
\hline Alsatian & 1 & & & 1 & $\begin{array}{l}\text { osteogenic } \\
\text { sarcoma }\end{array}$ & sternum & hemangioma & spleen \\
\hline Dachshund & & 1 & & 1 & $\begin{array}{l}\text { adeno- } \\
\quad \text { carcinoma }\end{array}$ & mamma & leiomyoma & vagina \\
\hline Collie & & 1 & & 1 & $\begin{array}{l}\text { adeno- } \\
\text { carcinoma }\end{array}$ & mamma & leiomyoma & uterus \\
\hline Great Dane & & 1 & & 1 & $\begin{array}{l}\text { mast cell } \\
\text { sarcoma }\end{array}$ & skin & adenoma & mamma \\
\hline Finnish harrier & 1 & & & 1 & seminoma & testis & $\begin{array}{c}\text { sebaceous gl. } \\
\text { adenoma }\end{array}$ & skin \\
\hline Airedale terrier & 1 & & & 1 & epithelioma & $\begin{array}{l}\text { oral } \\
\text { mucosa }\end{array}$ & fibroma & $\begin{array}{l}\text { subcut. } \\
\text { tissue }\end{array}$ \\
\hline Total & 5 & 4 & 1 & 8 & & & & \\
\hline
\end{tabular}

tumours. It was found that $65.2 \%$ of the malignant neoplasms were either cutaneous or mammary tumours.

The regional distribution of cutaneous tumours was investigated on samples of neoplasms with known localization only. The distribution of the cutaneous tumours in different regions of the body is shown in Fig. 6. About $1 / 3$ of the tumours were located in the extremities. No difference in distribution between the fore and hind extremities could be noted.

The multiple primary tumours investigated are presented in Table 5. Nine dogs showed 18 multiple primary tumours. No breed or sex predisposition was established. The youngest and oldest dog in this series were 4 and 13 years old. The mean age, $10 \pm 0.9$ years, is higher than the mean age of the entire material, but there is no statistically significant difference. The distribution of epithelial and mesenchymal tumours and of malignant and 
benign neoplasms showed no statistical divergence. No statistical dominance of any type of tumour was established. In 8 dogs malignant as well as benign tumours were noted simultaneously. One dog showed two different types of malignant tumours.

In view of the high mean age the observation could be made that multiple primary tumours occurred most commonly in older dogs.

The data concerning tumour metastases were incomplete, because only tissue specimens were available in 89 cases.

In the post-mortem material tumour metastases were most often found in the lungs. Other organs in which metastases were commonly observed were the liver, the spleen, the regional lymph nodes and the kidneys.

\section{DISCUSSION}

Some notable observations concerning the tumour susceptibility of different breeds have previously been published. Several authors agree that Boxers are predisposed to tumours. Their predisposition to carcinoma, to cutaneous tumours and to certain tumours of the mesenchymal and nervous tissues and endocrine glands has been demonstrated (Krook 1954; Larsson 1956, 1957; Cotchin 1962; Stünzi \& Lott-Stolz 1965; Howard \& Nielsen 1965). Also the susceptibility of some other breeds to a certain group of tumours, e. g. that of Great Danes to osteogenic sarcoma is obvious (Cotchin 1962). However, partly controversial opinions can be found in the existing literature in respect of the tumour susceptibility of certain breeds, such as the Fox terriers. In the following only investigations of interest to the present study will be considered.

Mulligan (1949 c) discussed the tumour susceptibility of certain breeds in detail. He observed among others that Fox terriers and Cocker spaniels have a high incidence of mammary tumour. However, the conclusions drawn by Mulligan (1949 c) were criticised by Krook (1954), who in his thorough investigations proved statistical analysis to be indispensable in determining susceptibility to tumours. In Krook's (1954) series, Fox terriers were resistant to carcinoma. Later, Larsson (1956) found them to be resistant to cutaneous tumours.

In the present material no susceptibility of Fox terriers to mammary tumours was established. On the other hand these tumours were common in Cocker spaniels. Statistically signifi- 
cant dominance of mammary tumours, however, could only be noted for Dachshunds. It would be interesting to make a detailed investigation of the tumour susceptibility of Fox terriers, Dachshunds and Cocker spaniels to mammary tumours on the basis of a sufficiently extensive material.

Also the susceptibility of Airedale terriers to carcinoma (Krook 1954) and the cutaneous tumours (Larsson 1956) has previously been investigated. The breeds which were statistically highly significantly over-represented in Krook's (1954) series were Airedale terriers, Boxers, Vorstehs and Setters. Since the mean age of the Boxers only was lower than the mean age of the canine population of Stockholm, Krook (1954) considered the over-representation of the Boxers to be an expression of predisposition to carcinoma. As regards Vorstehs and Setters, Krook (1954) observes that owing to their high mean age the over-representation need not necessarily be caused by a constitutional factor. He continues that "in principle the same applies to the Airedale terrier, but in this case the significance for carcinoma is very high while the average age is not very high, and therefore it is difficult to draw certain positive conclusions". In Larsson's (1956) material, too, Airedale terriers showed a statistically highly significant over-representation. Their mean age was higher than that of the Stockholm canine population, without any statistically significant difference. In spite of this, Larsson (1956) refrains from specifying any potential predisposition for Airedale terriers.

In the present material the over-representation of Boxers and Airedale terriers was statistically highly significant. The predisposition of Boxers to tumours, particularly cutaneous tumours, corroborates earlier investigation results. It also seems obvious that Airedale terriers possess some kind of constitutional disposition for tumours.

The influence of a potential resistance in the case of Finnish harriers and Finnish spitzes on their statistically highly significant under-representation remains undetermined. However, it seems possible that some factor or factors increasing the resistance to tumours exist in their constitution.

The sex distribution was dominantly female in most investigations (e.g. McClelland 1940; Krook 1954; Cotchin 1959). However, some cutaneous tumour series (e.g. Larsson 1956; Sedlmeier \& Weiss 1963) have been male-dominated. It seems there- 
fore indicated to discuss which factors may influence the sex distribution of the tumours.

The sex distribution of the canine population obviously has a decisive effect on the composition of the material. It is therefore necessary to compare the sex distribution of the material to that of the canine population. This kind of analysis has been performed by Mulligan (1949c) and Krook (1954, 1956). Mulligan (1949c) notes: "Correction of the number of neoplasms in both sexes by the number of each sex in the general population would seem to indicate a greater incidence of neoplasia in bitches". If Mulligan's (1949c) opinion is correct, the potential susceptibility of females would result in their over-representation. Krook (1954), however, is not prepared to accept as such Mulligan's (1949c) idea of the females' susceptibility, instead, he attributed the statistically highly significant over-representation of females in his material to the high incidence of mammary tumours.

Mammary tumours of females are frequent in various series. On the other hand, mammary tumours of males have not been noted or have been rare. If the mammary tumours and the tumours of the genitals are excluded, distinct male dominance can be observed in the author's material. These findings corroborate earlier observations published by Cotchin (1959). The susceptibility to mammary tumours of certain breeds, e.g. Dachshunds and according to Mulligan (1949c) Cocker spaniels, is evident. In the author's opinion the relatively strong representation of these breeds in the canine population as a whole is responsible for the frequency of mammary tumours and, indirectly, for the female-dominated sex distribution.

The distribution according to age, published in various reports, is fairly consistent. In the series of most investigators (e.g. Mulligan 1948a, 1949c; Krook 1954; Cotchin 1959; Wagstaff et al. 1967) as well as in the present material tumours occurred most frequently in dogs over 6 years of age, when the "cancer age" obviously begins.

The relative number of malignant tumours increases with age. The present investigations support the generally accepted view that tumours, especially malignant tumours, are lesions of the high age groups in dogs.

Examinations of tumours and their classification as presented in various reports reveal some differences, owing to the selection 
methods used. However, certain general features can be noted in the occurrence of different types of tumours.

In Mulligan's (1949c) material no great difference was observed in the distribution of epithelial and mesenchymal tumours. In most series malignant tumours dominate. Furthermore it may be noted that carcinomas are more common than sarcomas (Fölger 1917; Tamaschke 1951/52; Kronberger 1961). Kronberger stated that in his material the carcinoma/sarcoma ratio was $1.26: 1$. Obviously sarcomas are dominant in young dogs, but the incidence of carcinomas increases with advancing age (Überreiter 1960).

Among cutaneous neoplasms malignant growths are more common than benign tumours (Larsson 1956; Sedlmeier \& Weiss). Larsson (1956) did not establish any statistically significant difference in the distribution of epithelial and mesenchymal cutaneous tumours. According to Sedlmeier \& Weiss, however, epithelial tumours were dominant.

The distribution of tumours in the author's material is consistent with the above-mentioned observations. The dominance of malignant tumours was particularly high. Carcinomas were considerably more common than sarcomas at a ratio of $1.5: 1$. It seems evident on the basis of the available material that malignant tumours and especially malignant epithelial tumours are the most common tumours in dogs in Finland.

The distribution of tumours according to organs varies somewhat in different reports, obviously for the reason that in many of the series tumours found in post-mortem material as well as in tissue specimens have been investigated. Wagstaff et al. have closely studied and discussed the differences in the distribution of cancer between case series drawn from private practices and those drawn from a university clinic.

Most investigations show that cutaneous and mammary tumours constitute more than half of all types of neoplasms. Their frequency varies, but as a rule the cutaneous tumours dominate (e.g. Cotchin 1959; Mulligan 1948a, 1949c; Wagstaff et al.). The data stated by Cotchin (1959) concerning the distribution of tumours according to organs are highly representative. He reported that cutaneous tumours accounted for $37.5 \%$ of all tumours in his material. The next largest group, tumours of the female genitals including mammary tumours, comprised $25.9 \%$, and the number of mammary tumours alone was equivalent to 
$21 \%$. The third largest group in his series, $14 \%$, consists of tumours established in the digestive tract. The other groups represented were: tumours of the male genitals $(7.1 \%)$, the bones $(3.9 \%)$, the lymphatic organs $(3.8 \%)$ and other groups of organs $(7.6 \%)$.

In the author's material the distribution of tumours according to different organs and groups of organs is almost consistent with that reported by Cotchin (1959).

Multiple primary tumours are relatively rare in dogs. Mulligan (1944b) has reviewed the series of multiple primary tumours reported by other authors. Of 123 tumours established in 46 dogs, 58 were malignant and 65 were benign. The malignant tumours included 36 carcinomas and 21 sarcomas. About $21 \%$ of the tumours were neoplasms of the female genitals, about $21 \%$ tumours of the skin or subcutaneous tissues and about $10 \%$ tumours of the liver. The most common combination of tumours was either one malignant and one benign tumour, or two different malignant tumours. The breeds most commonly affected were Pinschers, Fox terriers and Dachshunds. Males and females were about equal in number. The mean age of these dogs was high, about $83 \%$ were older than 9 years.

In the author's opinion the most notable feature of the abovementioned statement as well as of the author's material is the high mean age of the dogs. Multiple primary tumours are very rarely encountered in young dogs.

The data concerning the metastasizing of tumours are deficient in most reports, because the neoplasms found at necropsy only constitute part of the entire material. In the present material metastases were frequently noted in the lungs, liver, spleen, regional lymph nodes and kidneys. These findings correspond on the whole to the relevant observations made by Moulton 1961 (p. 20).

\section{REFERENCES}

Cotchin, E.: Neoplasms in small animals. Vet. Rec. 1951, 63, 67-78.

Cotchin, E.: Further observations on neoplasms in dogs, with particular reference to site of origin and malignancy. Part I: Cutaneous, female genital and alimentary systems. Brit. vet. J. 1954a, 110, 218-229.

Cotchin, E.: Further observations on neoplasms in dogs, with particular reference to site of origin and malignancy. Part II: 
Male genital, skeletal, lymphatic and other systems. Brit. vet. J. 1954b, 110, 274-286.

Cotchin, E.: Neoplasms of the Domesticated Mammals. Review Series No. 4 of the Commonwealth Bureau of Animal Health. Commonwealth Agricultural Bureau, Farnham Royal, Bucks., England 1956.

Cotchin, E.: Some tumours of dogs and cats of comparative veterinary and human interest. Vet. Rec. 1959, 71, 1040-1050.

Cotchin, E.: Problems of comparative oncology. With special reference to the veterinary aspects. Bull. Wld Hlth Org. 1962, 26, 635-648.

Fölger, A. F.: Geschwülste bei Tieren. Ergebn. allg. Path. path. Anat. 1917, 18, 372-676.

Howard, E. B. \& S. W. Nielsen: Neoplasia of the Boxer dog. Amer. J. vet. Res. 1965, 26, 1121-1130.

Kronberger, H.: Kritische Sichtung des dem Institute in den Jahren 1917-1959 eingesandten Geschwulstmaterials von Haussäugetieren. Mh. Vet.-Med. 1961, 16, 296-302.

Krook, L.: A statistical investigation of carcinoma in the dog. Acta path. microbiol. scand. 1954, 35, 407-422.

$K r o o k, L .:$ On gastrointestinal carcinoma in the dog. Acta path. microbiol. scand. 1956, 38, 43-57.

Larsson, B.: Statistical analyses of cutaneous tumours in dogs, with special reference to Mastocytoma. Nord. Vet.-Med. 1956, 8, 130-139.

Larsson, B.: Some aspects of canine Mastocytoma. Nord. Vet.-Med. 1957, 9, 241-256.

McClelland, R. B.: Neoplasms in dogs. Cornell Vet. 1940, 30, 161, 162, $164,166$.

Moulton, J. E.: Tumors in Domestic Animals. University of California Press, Berkeley and Los Angeles 1961.

Mulligan, R. M.: Some statistical aspects of canine tumors. Arch. Path. (Chicago) 1944a, 38, 115-120.

Mulligan, R. M.: Multiple primary tumors in dogs. Cancer Res. 1944b, 4, 505-509.

Mulligan, R. M.: Statistical and histologic study of one hundred and twenty canine neoplasms. Arch. Path. (Chicago) 1948a, 45, $216-228$.

Mulligan, R. M.: Neoplastic diseases of dogs. II. Mast cell sarcoma, lymphosarcoma, histiocytoma. Arch. Path. (Chicago) 1948b, 46, 477-492.

Mulligan, R. M.: Neoplastic diseases of dogs. I. Neoplasms of melaninforming cells. Amer. J. Path. 1949a, 25, 339-355.

Mulligan, R. M.: Primary liver-cell carcinoma (hepatoma) in the dog. Cancer Res. 1949b, 9, 76-81.

Mulligan, R. M.: Neoplasms of the dog. The Williams \& Wilkins Company, Baltimore $1949 \mathrm{c}$.

Mulligan, R. M.: Comparative pathology of human and canine cancer. Ann. N.Y. Acad. Sci. 1963, 108, 642-690. 
Sedlmeier, H. \& E. Weiss: Zur Beurteilung der Hauttumoren von Hund und Katze. Berl. Münch. tierärztl. Wschr. 1963, 76, 181-185.

Stünzi, H. \& G. Lott-Stolz: Gedanken zur Krebsstatistik beim Hund. Mh. Vet.-Med. 1965, 20, 793-795.

Tamaschke, Chr.: Beiträge zur vergleichenden Onkologie der Haussäugetiere. Wiss. Z. Humboldt-Universität, Berlin 1951/52, 1, Heft 2, 37-77.

Tufvesson, G.: Operativ behandling av pyometra hos hund. Nord. Vet.Med. 1953, 5, 273-288.

Wagstaff, D. J., L. S. Goyings \& R. F. Langham: Canine cancer distribution as related to data source. Amer. J. vet. Res. 1967, 28, 1479 - 1482.

Überreiter, O.: Neubildungen bei Tieren. Wien. tierärztl. Mschr. 1960, $47,805-832$.

\section{SUMMARY}

The author presents a statistical investigation of tumours from 164 dogs examined at the Department of Pathology of the College of Veterinary Medicine, Helsinki, Finland.

It was found that Boxers and Airedale terriers were predisposed to tumours and especially to cutaneous neoplasms. The dominance of mammary tumours in Dachshunds was statistically highly significant. A statistically highly significant under-representation of Finnish harriers and Finnish spitzes was noted.

Sex distribution was female-dominated, obviously owing to high incidence of mammary tumours.

It was shown that tumours, especially malignant neoplasms, were primarily found in the high age groups.

No difference was observed in the frequency of epithelial and mesenchymal tumours. Malignant tumours were strongly dominant, obviously due to common incidence of carcinoma. The carcinoma/ sarcoma ratio was 1.5:1.

Analysis of the localization showed that cutaneous tumours $(37.0 \%)$ and mammary tumours of females $(19.1 \%)$ were most common.

Nine dogs showed 18 multiple primary tumours. The high frequency of these tumours in older dogs was obvious. Their mean age was $10 \pm 0.9$ year.

\section{ZUSAMMENFASSUNG}

Eine statistische Untersuchung über Geschwülste beim Hund.

Der Verfasser berichtet in einer statistischen Darstellung über Geschwülste von 164 Hunden, die im Institut für Pathologie der Veterinärmedizinischen Hochschule, Helsinki, Finnland, untersucht wurden.

Es wurde festgestellt, dass Boxer und Airedale Terrier eine Prädisposition für Geschwülste, besonders für Hautgeschwülste, zeigten. Die Dominanz von Mammatumoren bei Dachshunden war statistisch 
hoch signifikant. Eine statistisch hoch signifikante Unterrepräsentation von Finnischen Harriern und Finnischen Spitzen wurde beobachtet.

In der Geschlechtsdistribution wurde weibliche Dominanz festgestellt, bedingt durch das häufige Auftreten von Mammatumoren.

Es wurde beobachtet, dass Geschwülste, insbesondere die bösartigen Geschwülste, hauptsächlich in den hohen Altersgruppen auftraten.

Hinsichtlich der Häufigkeit von epithelialen und mesenchymalen Tumoren wurde kein Unterschied festgestellt. Bösartige Geschwülste dominierten stark, offensichtlich bedingt durch das häufige Auftreten von Karzinomen. Das Verhältnis Karzinom/Sarkom war 1,5:1.

Eine Analyse der Lokalisation zeigte, dass Hautgeschwülste $(37,0 \%)$ und weibliche Mammageschwülste $(19,1 \%)$ am häufigsten auftraten.

Neun Hunde wiesen 18 multiple Primärgeschwülste auf. Die Häufigkeit dieser Geschwülste in älteren Hunden war betont. Ihr durchschnittliches Alter war $10 \pm 0,9$ Jahre.

\section{SAMMANFATTNING}

En statistisk undersökning av tumörer hos hund.

Författaren presenterar en statistisk utredning över tumörer från 164 hundar undersökta å Institutet för Patologi, Veterinärmedicinska Högskolan, Helsingfors.

Utredningen visade att boxer och Airedale terrier voro predisponerade för tumörer, särskilt hudtumörer. En statistisk högt signifikant dominans av juvertumörer observerades hos taxhundar. Finsk stövare och finsk spets visade en högt signifikant underrepresentation.

Könsdistribution var dominant med avseende på honhundar, synbarligen orsakad genom markerad frekvens av juvertumörer.

Utredningen visade att tumörer, särskilt maligna tumörer, observeras främst hos de höga åldersgrupperna.

Med avseende på frekvensen av epiteliala och mesenkymala tumörer kunde inga olikheter observeras. Förekomsten av maligna tumörer var starkt dominant, synbarligen orsakad genom markerad frekvens av carcinomer. Carcinom/sarkom relationen var 1,5:1.

Analysering av lokalisationen visade, att kutana tumörer $(37,0 \%)$ och juvertumörer hos honhundar $(19,1 \%)$ visade den högsta frekvensen.

Hos 9 hundar observerades 18 multipla primära tumörer. Frekvensen av dessa tumörer hos äldre hundar var markerad. Medelåldern var $10 \pm 0,9$ år.

(Received May 24, 1968). 